\section{PRIMARY HEMORRHAGE INTO THE SPINAL CORD.}

To the Editors of THE LANCET.

SIRs, - I am prompted by reading in your issue of the 23rd inst. the report of a lecture by Dr. Sharkey on "Primary Hæmorrhage into the Spinal Cord," in which he speaks of it as a very rare disease, to send you the following brief note. In discussing its etiology, he mentions sudden hyperæmia as probably "the effective cause in sudden alterations of atmospheric pressure, such as occur in the case of divers." Such a case came quite recently under my notice. On May 14th W. P-, aged twentyeight, a petty officer in the Royal Navy, of remarkably fine physique and healthy appearance, was engaged in passing through a course of instruction in diving. The course had lasted for six weeks, and he was making his last dive at a depth of between twenty and twentyone fathoms. He had been down at the bottom for some ten minutes, when he was signalled to return to the surface. The officer in charge, observing that he was coming up much too quickly, tried to check him, but in vain; he reached the surface, ascending over $120 \mathrm{fb}$. in a minute and a half. When remonstrated with he said, laugh. ingly, that he was all right, and that as it was his last dip he wanted to see what sensation was produced by coming up rapidly. After taking off the helmet he complained of a pain in the stomach and of numbness of the legs. Finding that this numbness still continued he had the dress taken off and went on board an old hulk to walk up and down, and rub himself in order, as be said, to " restore the circulation." After the lapse of more than an hour he found himself worse and was brought on board this ship, when he was seen by me. I found him suffering from paraplegia from the waist downwards. He was quite unable to stand, but could move his legs easily when lying down. Sensation was much impaired, but he could feel a pin. It amounted to a feeling of numbness. The plantar reflex was increased. The pulse was 111, and there was no headache. Hæmorrhage into the spinal meninges was diagnosed, and he was sent to hospital. He passed then from under my care. The paralysis gradually spread upwards, and death occurred on the sixth day. At the necropsy the diagnosis was confirmed. The cause of this hæmorrhage was without doubt due to the sudden alteration in the atmospheric pressure, due time not having been allowed, by a slow ascent, for the proper equilibrium between the intra- and extra-vascular pressure to be established, and as a consequence capillary rupture ensued. The atmospheric pressure at 120 feet is over $52 \mathrm{lb}$. to the square inch, which will give some idea of the enormous pressure suddenly thrown upon the vascular system.

I am, Sirs, yours truly,

HERBERT M. ELLIS,

H.M.S. Cambridge, May 25th, 1891. Fleet Surgeon, Royal Navy.

\section{A TRIBUTE TO SURGEON PARKE.} To the Editors of THE LANCET.

SIRS,-If ever the Albert medal was deserved it is in the case of Dr. T. H. Parke. The story reported by Captain Stairs, and it is a pity Captain Stairs has not told the tale long before this, is one of almost incredible bravery and unselfishness. Although during the Stanley Expedition at very death's door from remittent bilious fever of fifteen days' duration, Dr. Parke crawled to the hut of a black chief in order to render him surgical relief. It would have been a glorious act of self-sacrifice if Dr. Parke had done this for a fellow Englishman, but to have done it for a black man makes the act, I am sure, one which has never been surpassed. I trust, Sirs, that you will use your influ. ence to ensure the reward of the Albert Medal to this great hero, and may most of us be present at its bestowal.

I am, Sire, yours faithfully,

Canterbury, May 24th, 1891. Pugin THORNTON.

\section{"LIFE ASSURANCE WITHOUT MEDICAL EXAMINATION."}

To the Ealitors of THE LANCET.

SIRS,-In your issue of the 9 th inst. you made mention of the accounts of this company up to Dec. 31st last, and you referred, in particular, to the anount of the claims paid in 1890 as compared with 1889 , suggesting that an abnormal increase in claims took place last year. I am instructed by my directors to point out to you that in comparing our revenue account for the year 1890 with the revenue account for the year 1889 you are comparing two different things. The account for the year 1889 shows the claims before the business of the "Scottish Provincial" Company was on Jan. 31st, 1890, transferred to us ; while the account for the year 1890 includes not only "North British and Mercantile" claims, but also claims under "Scottish Pro. vincial" policies during eleven months of that year. If the amount of these "Scottish Provincial" claims-viz., $£ 124,000-$ be deducted from the total in our account, it is seen that the amount paid under "North British and Mercantile" policies is $£ 335,000$ odd, a sum approximating: closely to the totals for the years 1888 and 1889 , and presenting no abnormal feature. The claims under Civi Service policies, embraced in our account for 1890 , amount to $£ 3400$. As the statement which you have made is calculated to mislead the public, it is hoped that you will publish this letter in your next impression.

I am, Sirs, your obedient servant, HENRY Cockburn, Manager and Actuary.

North British and Mercantile Insurance Office, 61, Threadneedlestreet, London, E.C., May 22 nd, 1891 .

\section{POLLOCK AND BELLAMY MEMORIAL FUND.}

\section{To the Editors of THE LANCET.}

SIRs, - Will you be so good as to give me space in your columns to acknowledge the subscriptions to the Pollock and Bellamy Memorial Fund, as per list enclosed? Allow me to thank you for the very kind notice of the meeting of the subscribers to this fund which you inserted in your issue of last week. I am, Sirs, yours faithfully,

134, Harley-street, W., May 27th, $1891 . \quad$ STAN LEY BoYD.

\section{FIRST LIST OF SUBSCRIBERS.}

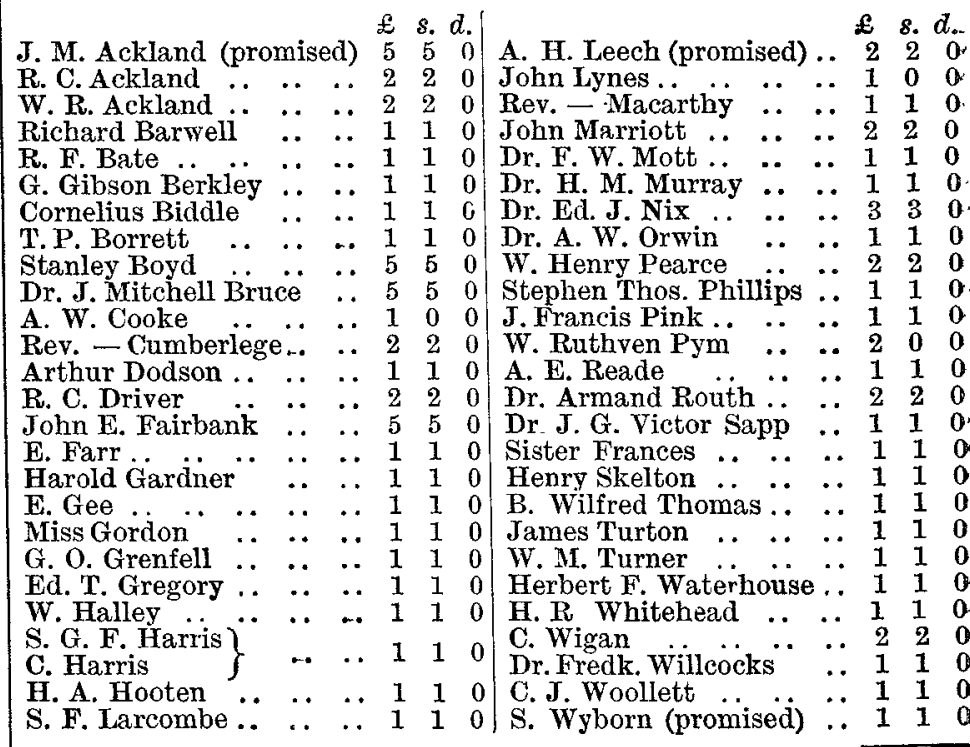

Other smaller sums making the total up to

\section{BIRMINGHAM.}

(From our own CoRrespondent.)

\section{The late Mr. T. H. Bartleet.}

IT is proposed to found some memorial of the late $\mathbf{M r}$. Bartleet in recognition of his twenty-four years' service as Surgeon to the General Hospital, and in memory of the many high personal qualities and public spirit he exhibited. The subscription is limited to three guineas. It is not decided as to the form which the memorial shall take:. many of his friends, looking upon his connexion with the hospital as the paramount one in his life, are anxious that $a$ stained glass window should be erected in the new hospital. This would adorn the building, and would be a pleasant as. well as fitting tribute.

The Vacant Post.

The lamented death of Mr. Bartleet creates a vacancy on the surgical staff of the General Hospital. At present there 